\title{
Will We Soon Run Out of Water?
}

\author{
Ghislain de Marsily \\ Sorbonne University and French Academy of Sciences, Paris, France
}

Keywords

Water $\cdot$ Food $\cdot$ Agriculture $\cdot$ Food production scenarios

Abstract

In 2000, the World population was 6.2 billion; it reached 7 billion in 2012 and should reach 9.5 billion $( \pm 0.4)$ in 2050 and 11 billion $( \pm 1.5)$ in 2100 , according to UN projections. The trend after 2100 is still one of global demographic growth, but after 2060, Africa would be the only continent where the population would still increase. The amount of water consumed annually to produce the food necessary to meet the needs varies greatly between countries, from about 600 to $2,500 \mathrm{~m}^{3}$ /year per capita, depending on their wealth, their food habits (particularly meat consumption), and the percentage of food waste they generate. In 2000, the total food production was on the order of 3,300 million tons (in cereal equivalents). In 2019, about 0.8 billion inhabitants of the planet still suffer from hunger and do not get the nutrition they need to be in good health or, in the case of children, to grow properly (both physically and intellectually). Assuming a World average water consumption for food of 1,300 $\mathrm{m}^{3} /$ year per capita in $2000,1,400 \mathrm{~m}^{3} /$ year in 2050 , and $1,500 \mathrm{~m}^{3} /$ year in 2100 , a volume of water of around $8,200 \mathrm{~km}^{3} /$ year was needed in 2000,13,000 km³ year will be needed in 2050 , and $16,500 \mathrm{~km}^{3} /$ year in 2100 . Will that much water be available on earth? Can there be conflicts related to a food deficit? Some preliminary answers and scenarios for food production will be given from a hydrologist viewpoint.

(C) 2021 The Author(s)

Published by S. Karger AG, Basel

karger@karger.com www.karger.com/anm

Karger $\stackrel{\text { ' }}{=}$

BOPEN ACCESS
(C) 2021 The Author(s)

Published by S. Karger AG, Basel

This article is licensed under the Creative Commons AttributionNonCommercial-NoDerivatives 4.0 International License (CC BY NC-ND) (http://www.karger.com/Services/OpenAccessLicense). Usage and distribution for commercial purposes as well as any distribution of modified material requires written permission.

\section{Introduction}

The water that we use has two origins: the freshwater stocks and the natural water cycle.

\section{Freshwater Stocks on Earth}

The water we use comes to $95 \%$ from the renewable water cycle, and only to about 5\% from the freshwater stocks on earth, which are, however, very large (see e.g., [3]): about 28.2 million $\mathrm{km}^{3}$ of ice and 15 million $\mathrm{km}^{3}$ of groundwater (which may be brackish in many places), plus about 0.3 million $\mathrm{km}^{3}$ in lakes, and $8,500 \mathrm{~km}^{3}$ in artificial reservoirs [4]. The ice stock is decreasing because of climate change warming, and today the flow in the rivers from high mountains with glaciers is increased because of the melting ice.

The groundwater stocks are also decreasing $[5,6]$. The global amount of irrigation water used in the World in 2000 was $2,510 \mathrm{~km}^{3} /$ year, out of which $734 \mathrm{~km}^{3} /$ year came from groundwater, including 130 to $250 \mathrm{~km}^{3} /$ year taken from the stocks (i.e., larger withdrawals than the average annual recharge by rainfall). India, Pakistan, USA, China, Iran, and Mexico are the major countries where such excess withdrawals are occurring. But about $5-10 \%$ of today's irrigation water is non-sustainable since groundwater stocks will eventually dry out. This is of special concern for India and China, where the stocks will last for about 10-30 years.

This article is partly based on references [1, 2].

Ghislainde Marsily

CNRS Mixed Research Unit METIS, Sorbonne University

Pierre et Marie Curie Campus

FR-75252 Paris (France)

gdemarsily@aol.com 
Table 1. Climate classification adapted from [11] and life zones from [12], in [10]

\begin{tabular}{lllrl}
\hline & Aggregated Holdridge life zones & $\begin{array}{l}\text { Continental } \\
\text { surface, } \%\end{array}$ & $\begin{array}{l}\text { Population, } \\
\%\end{array}$ & $\begin{array}{l}\text { Global discharge } \\
\text { (Blue Water), \% }\end{array}$ \\
\hline Polar and cold & Tundra and polar; cold parklands & 14.8 & 3.2 & 11.9 \\
Cool & Forest tundra; boreal forest & 11.3 & 4.0 & 11.6 \\
Temperate & Temperate forest; warm temperate forest & 9.9 & 23.3 & 15.2 \\
Steppe & Steppe; chaparral & 9.7 & 13.6 & 1.9 \\
Arid & Cool desert; hot desert & 18.5 & 7.9 & 0.3 \\
Subtropical & Tropical semi-arid; tropical dry forest & 18.3 & 24.8 & 8.8 \\
Humid tropical & Tropical seasonal forest; & 17.5 & 23.2 & 50.3 \\
& tropical rain forest & & & \\
\hline
\end{tabular}

\section{The Water Cycle}

The renewable freshwater resources of planet earth, adapted from $[7,8]$, are estimated today at $113,000 \mathrm{~km}^{3} /$ year, which is the total amount of rainfall and snowfall on the continental surfaces including the Antarctic and Greenland ice sheets. The fate of this rainwater is:

1. $73,000 \mathrm{~km}^{3} /$ year $(65 \%)$ is stored in the topsoil layer and returns to the atmosphere, mostly by plant transpiration and by direct evaporation. This amount is used by rain-fed agriculture and pasture (in 2000, $6,300 \mathrm{~km}^{3} /$ year) and sustains the needs of all terrestrial ecosystems. It is now called "Green Water" [9].

2. $4,000 \mathrm{~km}^{3} /$ year $(3 \%)$ represents the melting of icebergs, broken-off from the Antarctic and Greenland ice sheets, which melt in the sea.

3. $36,000 \mathrm{~km}^{3} /$ year $(32 \%)$ is the total flow on the continents, which is called "Blue Water" [9]: 26,000 $\mathrm{km}^{3} /$ year of direct run-off into rivers when it rains, plus $10,000 \mathrm{~km}^{3} /$ year infiltrated into the ground beneath the topsoil layer and feeding the aquifers, which in turn feed the rivers $\left(7,800 \mathrm{~km}^{3} /\right.$ year $)$, or flowing directly into the seas or endorheic zones $\left(2,200 \mathrm{~km}^{3} /\right.$ year).

In general, the volume of Green Water is not considered a resource, only the flowing water in rivers or aquifers is taken into account, which constitutes a major error since, for the year 2000, of the estimated $8,200 \mathrm{~km}^{3} /$ year of water consumed ${ }^{1}$ by agriculture for food, about 6,300 $\mathrm{km}^{3} /$ year is Green Water, and only $1,800 \mathrm{~km}^{3} /$ year is Blue

\footnotetext{
1 The "consumed" water is that which is evaporated and returns to the atmosphere; in irrigation, it represents on average $75 \%$ of the withdrawal; in domestic and industrial use, it represents about $15 \%$ of the withdrawal, and the rest is the return flow which goes back to the continental water cycle.
}

Water, used for irrigation, see Table 3. The total surface area of the continents is 13.3 billion ha, of which approximately 1.6 is farmland, 3.7 is forest, 4.6 is grass and shrub, and 3.4 is bare land; the total area that could potentially be farmed, at the expense of forests and grass and shrub, is 4.2 billion ha.

However, the arable land that is not directly farmed today, about 2.6 billion ha, is not bare soils: it contains all the remaining natural ecosystems, from the tropical forests to the northern forests, the grasslands, the bush land, the wetlands, etc. Transforming more land into farmland for agriculture, therefore, has an environmental cost of reducing natural ecosystems and biodiversity.

Thus the global renewable resource of freshwater on Earth (total rainfall on the continents) is very large, and today less than $10 \%$ of it is used by humans, but the remaining $90 \%$ are entirely used to sustain the natural ecosystems and the biodiversity. Globally, it may be possible to increase the part of the resource used by humans but only at the expense of the functioning of the natural ecosystems.

The water resource is unequally distributed on earth. At high latitudes (cold deserts), precipitation is very low, less than $200 \mathrm{~mm} /$ year. Rainfall increases in the temperate zone, where it reaches $700-1,000 \mathrm{~mm} /$ year, then decreases (at the latitude of the Mediterranean zone) to practically zero at the latitude of the "hot deserts," such as the Sahara, the Arabic Peninsula, the Taklimakan desert, Mexico, etc. It then increases again in the tropical and equatorial zones, to reach an order of $2,300 \mathrm{~mm} /$ year. The same type of climate distribution is found for every meridian and in both hemispheres.

Viviroli et al. [10] have estimated the percentage of the World population as a function of the climate and vegetation zones, with the amount of direct river run-off they receive (Table 1 ). 
The World population is not distributed in accordance with the water resource. Figure 1 also shows the areas of the World with current water shortages from [13-16], based on Blue Water only. Two causes are outlined on this map: (i) physical water scarcity, where more than $75 \%$ of the river flow (Blue Water) is withdrawn for human use and (ii) economical water scarcity, where the Blue Water is available, but not exploited for lack of resources to finance the equipment (dams, canals, irrigation systems...). This zone of "economical scarcity" harbours the 0.8 to 1 billion undernourished inhabitants of the planet today, not the "physical scarcity" zone. This is very important to realize, hunger is not, today at least, linked to a lack of water.

\section{Virtual Water, Example of Tunisia}

"Virtual water" [17] represents the amount of water needed to produce goods that are imported or exported from one country to another. Here, the goods are agricultural products. Let us consider the case of Tunisia, a country in the arid zone, see $[18,19]$. Tunisia has a surface area of $164,420 \mathrm{~km}^{2}$ and had 10 million inhabitants in 2004. It has about 5 million ha of agricultural land, $11 \%$ of which can be irrigated. The average rainfall is $220 \mathrm{~mm} /$ year, that is, a rainfall resource of $36 \mathrm{~km}^{3} /$ year. Total hydraulic resources (Blue Water) are estimated at $5 \mathrm{~km}^{3} /$ year, that is, $3 \mathrm{~km}^{3} /$ year of run-off and $2 \mathrm{~km}^{3} /$ year of groundwater. 2.1 $\mathrm{km}^{3} /$ year of surface water can be exploited through dam construction, and $1.8 \mathrm{~km}^{3} /$ year can sustainably be supplied by groundwater. The Green Water infiltrated into the soil and available for evaporation and consumption by plants is $23 \mathrm{~km}^{3} /$ year, of which $13 \mathrm{~km}^{3} /$ year refer to the whole extent of arable land (5 million ha), and $10 \mathrm{~km}^{3}$ / year to forest and rangeland. The remaining part of the rainfall is evaporated on bare soils and by wetlands or transferred to the Mediterranean.

The water demand for food is estimated from the amount of water needed to produce it (Table 2). Animal products are very demanding compared to vegetal products because animals eat vegetal products, with a low efficiency of transformation.

Based on the average Tunisian diet, the food water demand in 2004 was about $1,450 \mathrm{~m}^{3} /$ year per capita, while it was only $600 \mathrm{~m}^{3} /$ year in 1960 . This strong increase is due to diet changes by an increase of animal product consumption. With 10 million inhabitants in 2004, the water demand for food was $14.5 \mathrm{~km}^{3} /$ year, when the available water resource for agricultural production was $10 \mathrm{~km}^{3} /$

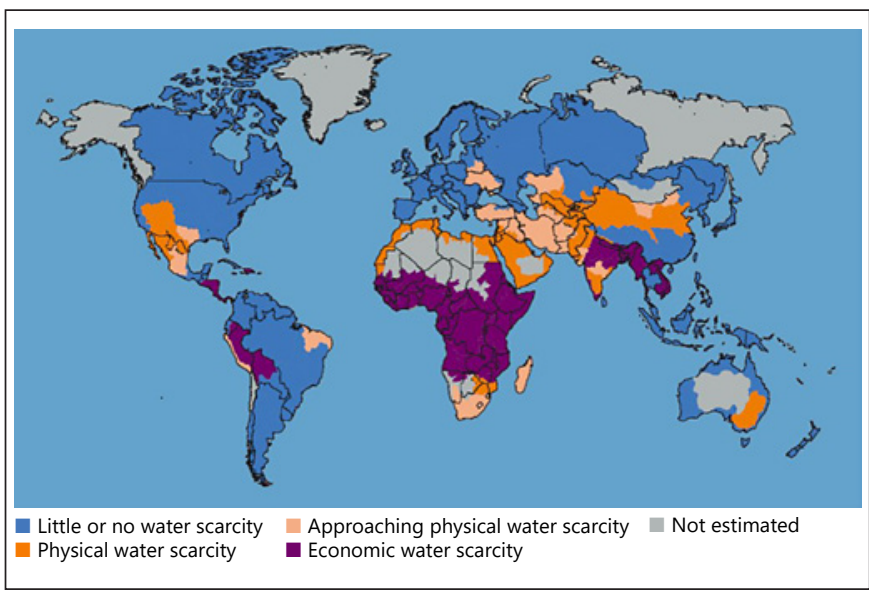

Fig. 1. Physical and economic water scarcity, from [15].

Table 2. Water needed for food production. Average values of water used in $\mathrm{m}^{3} / \mathrm{t}$ to produce raw food (consumed fraction, not in dry matter), from $[6,20]$

\begin{tabular}{|c|c|c|c|}
\hline Vegetal product & $\begin{array}{l}\text { Water needed, } \\
\mathrm{m}^{3} \mathrm{t}^{-1}\end{array}$ & $\begin{array}{l}\text { Animal } \\
\text { product }\end{array}$ & $\begin{array}{l}\text { Water needed, } \\
\mathrm{m}^{3} \mathrm{t}^{-1}\end{array}$ \\
\hline Vegetable oil & 5,000 & Beef & 13,000 \\
\hline Rice & $1,500-2,000$ & Poultry & 4,100 \\
\hline Wheat & 1,000 & Eggs & 2,700 \\
\hline Corn & 700 & Milk & 800 \\
\hline Citrus fruits & 400 & & \\
\hline Vegetables & $200-400$ & & \\
\hline Potatoes & 100 & & \\
\hline
\end{tabular}

year (Irrigation, Blue: 2 and Rain-fed, Green: 8). Tunisia was, therefore, in theory, short of about $5 \mathrm{~km}^{3} /$ year to meet its food demand and was obliged to import food (mostly cereals) as "virtual water" to balance its water budget. The direct water needs, which include municipalities, industry, and tourism, are small (3\%) compared to the agricultural demand.

Sometime in the 1980s, by its demographic growth and food diet changes, Tunisia became no longer self-sufficient in its food budget (or its water budget). To balance its financial budget, Tunisia needs to export products or services to raise the money needed for food import: phosphates minerals, textiles, tourism, services, or funds transfer from the diaspora. Provided that food is available on the international market, the real problem of Tunisia, given its demographic situation, is not water, and it is how to raise the money needed to buy food in the international market. de Marsily 


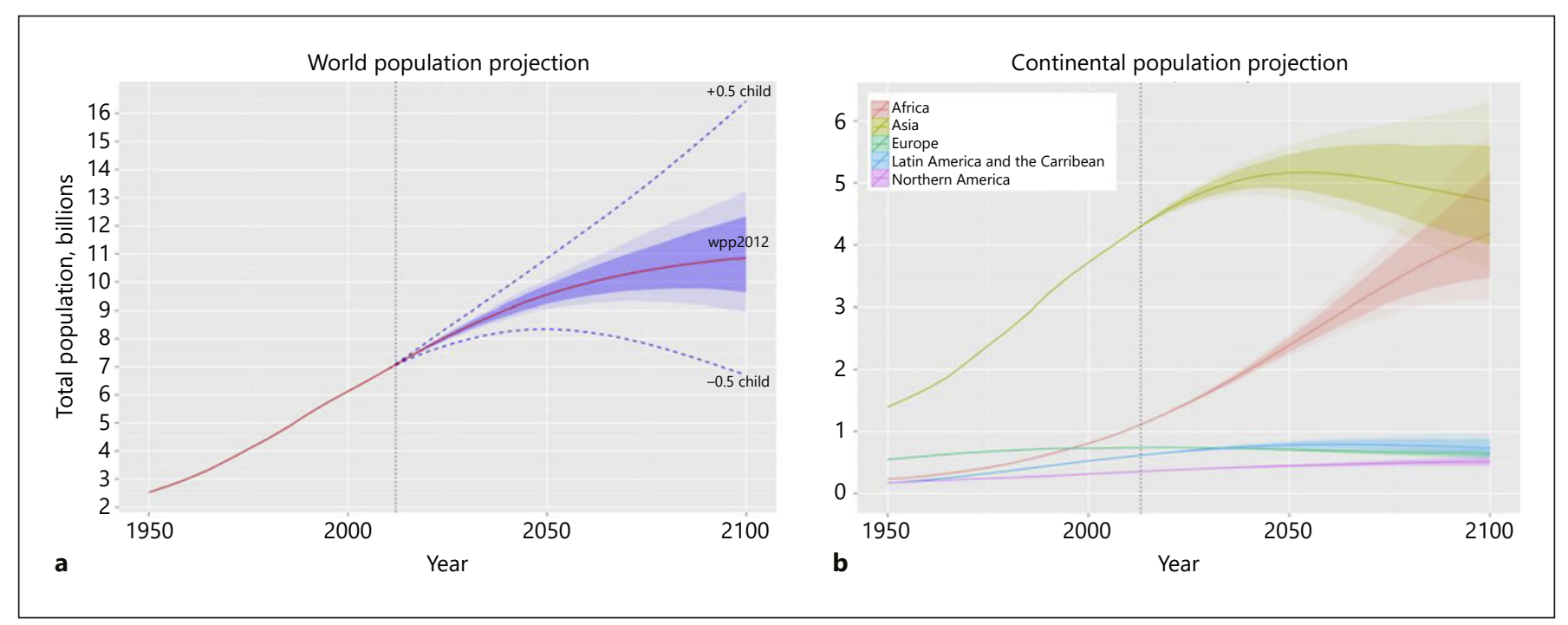

Fig. 2. Demographic growth as projected by the UN in 2012, from [27]. World and continental population projections. a UN 2012 World population projection (solid red line), with $80 \%$ prediction interval (dark shaded area), 95\% prediction interval (light shaded area), and the traditional UN high and low variants (dashed blue lines). b UN 2012 population projections by continent. In both panels, the vertical dashed line denotes 2012 .

\section{Scenarios for Food Production in 2050}

Table 3 (part 1, situation in 2000) is an estimate for 2000 of how much food the Planet produced, with a zonation taken from [21]. Listed per zone are area, area suitable for agriculture, water resources (rain, green, and blue water, potentially exploitable blue water), cultivated area in 2000, percentage of cultivated arable land, population, food need, in million tons of cereal-equivalent, average yield in $t / h a$, amount of water consumed (blue water, green water, and \% of rainfall), food deficit or excess, and finally, amount of arable land that is not cultivated and kept as "natural areas."

As shown in Table 3, the water consumed by agriculture for the planet in 2000 was $8,140 \mathrm{~km}^{3} /$ year: 1.34 billion ha of rain-fed agriculture, consuming $5,500 \mathrm{~km}^{3}$ /year; 3.3 billion ha of rain-fed pasture, consuming $840 \mathrm{~km}^{3} /$ year; and 234 million ha of irrigated agriculture, consuming $1,830 \mathrm{~km}^{3} /$ year. Three major cereals, rice, wheat, and maize, each representing approximately one-third, constitute $60 \%$ of the food consumption. The total food production is about 3.3 billion tons of cereal-equivalents per year, for 6.2 billion people. However, about 1 billion are undernourished; the amount of the food deficit is about 40 million tons/year, mostly in Asia and sub-Saharan Africa (Fig. 1). The food yield is on average $2.11 \mathrm{t} /$ ha but varies greatly from 0.75 (Russia and the Commonwealth of Independent States, CIS), 0.92 (sub-Saharan Africa, SS-
Africa) to about 2.9 (Asia and the countries of the OECD). The water efficiency $\left(\mathrm{m}^{3}\right.$ of water used to produce $1 \mathrm{t}$ of cereals) is on average $2,460 \mathrm{~m}^{3} / \mathrm{t}$, with SS-Africa at 6,150 $\mathrm{m}^{3} / \mathrm{t}$, Russia + CIS at 4,600 $\mathrm{m}^{3} / \mathrm{t}$, and OECD at $1,040 \mathrm{~m}^{3} / \mathrm{t}$. Note, however, that on average, at the global scale, one ha of irrigated land produces about 3 times more food than one ha of rain-fed land according to [26].

The major problems are expected to occur in Asia and in the West Asia-North Africa (WANA) countries, where the ratio of consumed water (Blue + Green) to rainfall is about $16 \%$ (World average: $8 \%$ ) and the ratio of farmland to arable land is 75 and $87 \%$, respectively (World average: $37 \%)$. The major issue concerning food is the availability of arable land, not water. The consumed water is on World average $78 \%$ green water and $22 \%$ blue water, but again Asia and WANA have quite different ratios: 70\% green, $30 \%$ blue, and $53 \%$ green, $47 \%$ blue, respectively. "Natural" land (arable land, i.e., not cultivated) is mostly found in Latin America (33\% of the total), sub-Saharan Africa (31\%), and OECD countries (19\%). To predict the food balance for the years 2050 or 2100 , one needs the World population, its eating habits, and the wasted food, the efficiency of food production.

1. Recent UN demographic projections [27] and Figure 2 converge towards 9.5 billion inhabitants in 2050 and towards 11 billion in 2100 .

2. Eating habits and wasted food are more difficult to predict. Table 2 [20] shows the amount of water need- 
Table 3. Estimates for the years 2000 and 2050 of the planet food production, based on the cultivated area of agricultural land, yields, global amount of water consumed (not withdrawn) by humans from the water cycle (Blue and Green Water), and food needs (adapted from $[1,3,6,14,22-25])$

\begin{tabular}{|c|c|c|c|c|c|c|c|}
\hline Area & Asia & $\begin{array}{l}\text { Latin } \\
\text { America }\end{array}$ & WANA & $\begin{array}{l}\text { Sub-Saharan } \\
\text { Africa }\end{array}$ & OECD & $\begin{array}{l}\text { Russia + } \\
\text { CIS }\end{array}$ & World \\
\hline Area, million ha & 2,090 & 2,070 & 1,180 & 2,430 & 3,380 & 2,190 & 13,340 \\
\hline \multicolumn{8}{|l|}{ Situation in 2000} \\
\hline Area suitable for agriculture, million ha & 585 & 1,066 & 99 & 1,031 & 874 & 497 & 4,152 \\
\hline \multicolumn{8}{|l|}{ Water resources, thousands of $\mathrm{km}^{3} /$ year } \\
\hline Blue water & 9.8 & 13.2 & 0.25 & 4.4 & 8.1 & 4 & 39.7 \\
\hline \multirow[t]{2}{*}{ Exploitable blue water and ratio to total blue water } & 9.3 & 8.7 & 0.24 & 4.1 & 5.6 & 1.8 & 29.7 \\
\hline & $95 \%$ & $66 \%$ & $96 \%$ & $93 \%$ & $69 \%$ & $45 \%$ & $75 \%$ \\
\hline Cultivated area, million ha (2000) & 439 & 203 & 86 & 228 & 377 & 255 & 1,564 \\
\hline Cultivated, $\%$ & 75 & 19 & 87 & 22 & 43 & 51 & 37 \\
\hline Population, million & 3,322 & 538 & 372 & 706 & 987 & 279 & 6,200 \\
\hline \multicolumn{8}{|l|}{ Water consumed, thousands $\mathrm{km}^{3} /$ year } \\
\hline Blue + green & 3.6 & 1.03 & 0.27 & 1.23 & $\sim 1.12$ & 0.89 & 8.14 \\
\hline Rainfall, \% & 16 & 3.3 & 15 & 6 & 5 & 10 & 8 \\
\hline Blue water for irrigation, $\%$ & $\sim 30$ & 11 & 53 & 3 & $\sim 17$ & 21 & 22 \\
\hline Green water, $\%$ & $\sim 70$ & 89 & 47 & 97 & $\sim 83$ & 79 & 78 \\
\hline Food deficit/Excess million tons/year & -40 & +75 & -75 & -50 & 50 & 0 & -40 \\
\hline Protected areas, million ha & 156 & 866 & 14 & 813 & 497 & 242 & 2,588 \\
\hline \multicolumn{8}{|l|}{ Situation expected in 2050} \\
\hline \multicolumn{8}{|l|}{ Variation of area suitable for agriculture due to } \\
\hline climate change, million ha & -40 & -40 & -10 & -20 & +80 & +80 & +50 \\
\hline Resulting area available for agriculture & 545 & 1,026 & 89 & 1,011 & 954 & 577 & 4,202 \\
\hline \multicolumn{8}{|l|}{ Production scenario, 2050} \\
\hline Food deficit/excess, million tons/year & -660 & +605 & -285 & 0 & +245 & +95 & 0 \\
\hline Protected areas, million ha & 65 & 480 & 0 & 293 & 497 & 242 & 1,577 \\
\hline
\end{tabular}

All these numbers are highly uncertain and sometimes based on the assumption of a linear proportion with the population. They are only orders of magnitudes, not precise estimates. WANA, West Asia and North Africa.

ed to produce the different types of food, and Table 3 the water actually used per geographic zone and the yield.

3. Agricultural water efficiency (Table 3) is assumed to increase by $20 \%$ by 2050 ; the same amount of food could be produced with $20 \%$ less water. When the yield is good (above to $2-3 \mathrm{t} / \mathrm{ha}$ ), the water consumption per ton is about that of Table 2, but when the yield is low (about $1 \mathrm{t} / \mathrm{ha}$ ), the water consumption per ton becomes much higher (up to 8 times more) because the plants are less developed, they do not cover the soil, and much water is evaporated, not transpired $[6,22]$. Griffon [23], Agrimonde [24], and Food and Agricultural Organization [25], for instance, have built scenarios 
of food needs and food production increase for 2050. One such scenario is presented in Table 3, part 2, for 2050. Compared to 2000, the increase in food production should be from 3,300 million t/year to 6,180 million $t /$ year. This number takes into account population growth, the age of the population, the eradication of hunger, and diet changes as a linear continuation of what happened in the past 10 years. This food production increase can be obtained by:

- increasing yields and crop efficiency,

- increasing the amount of irrigated land,

- increasing the amount of cultivated rain-fed land,

- reducing food losses, currently estimated at $30 \%$ of food production [28].

At present, the rate of areal increase in irrigated land is low, less than 2 million ha/year. The limiting factor is soils for Asia, and water for WANA. SS-Africa is currently in food deficit, but there is plenty of arable land and water in SS-Africa, and it could be self-sufficient, as assumed in Table 3, but this requires rapid development of the agricultural production in SS-Africa, which may or may not occur. In this scenario, the deficits from Asia and WANA are met by extra production by Latin America, OECD countries and Russia-CIS. In 2050, an increase of about 1 billion ha of rain-fed land would be required, at the expense of the "protected areas." This number is probably excessive; other scenarios produce half or even a third of that number. If this scenario is extrapolated to 2100 , with 11 billion inhabitants, a total production of 7,200 million tons/year of cereal-equivalents would be required, with an additional increase of rain-fed cultivated land of about 0.4 billion ha, and a residual "protected area" of 1.2 billion ha, instead of 2.6 today. Water desalination, often mentioned as the solution, is not a realistic option for food production, given its cost and energy requirements (from 2.5 to $6 \mathrm{kWh} / \mathrm{m}^{3}$ for seawater with reverse osmosis).

\section{Conclusions}

As predicted by the UN in 2012, the World population growth will put the planet under intense pressure to produce what will be needed to feed this population, with little place left for producing second-generation biofuels. Water will not be the limiting factor of food production at the global scale: there is plenty of water on earth, mostly through the water cycle. The major source of water to be used for food production is Green Water, that is, rainwater infiltrated into the upper soil and available to the vegetation for evapotranspiration. The real limiting factor for food production is the availability of agricultural soils that can be farmed, and which need to be protected.

The forecast for 2050 is that Asia (the whole continent) will not be able to feed itself due to a lack of arable land, and WANA even less so, due to a lack of water. Sub-Saharan Africa could have enough water and soils to feed itself, but if and only if, intensive agricultural development takes place, mostly by increasing rain-fed agriculture and its yields, and developing irrigation. The food deficit in Asia and WANA (and in SS-Africa if the required development is not sufficient) will have to come from the three remaining zones: OECD countries, which therefore need to increase their production (through irrigation, yield increase and new land farming), Russia and the CIS countries (mostly through yield increases), and lastly South America (through deforestation); all three zones will have to export "virtual water" to the countries with a food deficit. Sea transport of food is cheap and does not significantly harm the environment. In places where soils and water are available, but not in the same place (e.g., China, India, etc.), increasing irrigation by long-distance water transfers will be required.

For the countries that will need to import food, the real problem is to generate, by exports, the income required to pay for this import. For countries with both arable land and water, which are willing to increase their food production, two options are available: building dams and irrigation systems, or increasing the area of rain-fed agriculture, by deforestation. Both options have very negative consequences for the environment. Each situation may be different, and the two options need to be compared in each individual case, but irrigation is very efficient in reducing the surface area of land that needs to be farmed, since, on a global average, 1 ha of irrigated land produces three times more food than 1 ha of rain-fed land.

However, the World can sometimes experience very severe food deficits, both spatially and temporally, when the rains fail. In such situations, tragic conflicts or genocide can happen. The monsoon zone seems to be the most fragile in that respect, with historical famines which had extremely severe death tolls, for example, in the 19th century, most likely linked to very strong El Niño events, lasting several years. Very intense volcanic eruptions can also have drastic effects on rainfall, temperature, and global food production. The World is not protected against such food deficits, even if the last large famines occurred more than a century ago. To protect the World population against such events, one must create food stocks. Yet economists do not favour food stocks because 
of their costs or because they consider them only as regulators of market prices. On March 6, 2015, China indicated, however, that it would increase by $33 \%$ its budget for agricultural stocks, up to 24 billion dollars or from 200 million tons to 250 . This looks as a very wise decision, and other countries should follow that route. In case of severe droughts or food deficits, major conflicts or genocides are indeed likely to occur, as in Rwanda in 1994.

\section{Statement of Ethics}

This research did not involve human studies and, therefore, does not need to comply with the guidelines of human studies.

\section{Conflict of Interest Statement}

G.M. received travel expenses and registration fees from Danone Research to attend the 2019 Hydration for Health Scientific Conference, and the author declares no other conflicts of interest.

\section{References}

1 de Marsily G, Abarca Del Rio R. Water and food in the twenty-first century. Surv Geophys. 2016;37:503-27.

2 de Marsily G, Abarca Del Rio R, Cazenave A, Ribstein P. Allons-nous bientôt manquer d'eau? La Météorologie. 2018.101-39-49

3 de Marsily G. L'eau, un trésor en partage. Paris: Dunod; 2009. p. 256.

4 Chao BF, Wu YH, Li YS. Impact of artificial reservoir water impoundment on global sea level. Sciencexpress. 2008. Available from: www.sciencexpress.org

5 Wada Y, Van Beek LPH, Bierkens MFP. Nonsustainable groundwater sustaining irrigation: a global assessment. Water Resour Res. 2012:48.

6 Zimmer D. L'empreinte eau. Les faces cachées d'une ressource vitale. Paris: Charles Léopold Meyer; 2013. p. 212.

7 Shiklomanov IA, Rodda JC, editors. World water resources at the beginning of the twenty-first century. Cambridge, UK: Cambridge University Press; 2003.

8 Trenberth KE, Smith L, Qian T, Dai A, Fasullo J. Estimates of the global water budget and its annual cycle using observational and model data. J Hydrometeorol. 2007;8(4):75869.

9 Hoekstra AY, Mekonnen MM. The water footprint of humanity. Proc Natl Acad Sci U S A. 2012;109(9):3232-7.

10 Viviroli D, Dürr HH, Meybeck M, Weingartner R, Messerli B. Mountains of the world: water towers for humanity. Typology, mapping and global significance. Water Resour Res. 2007;43(7):W07447.
11 Leemans R. Global holdridge life zone classifications. Global Ecosystems Database Version 2.0. Boulder, CO, USA: NOAA National Geophysical Data Center; 1992.

12 Holdridge LR. Life zone ecology. San José (Costa Rica): Tropical Science Center; 1967. p. 206.

13 Rijsberman FR. Water scarcity, fact or fiction? Agricultural Water Management; 2006. 80-13-5-22.

14 IWMI. Water for food, water for life. The comprehensive assessment of water management in agriculture. In: Molden D, editor. Colombo, Sri Lanka. Earthscan, London: International Water Management Institute; 2007.

15 WWAP United Nations Educational, Scientific and Cultural Organization (UNESCO), United Nations World Water Assessment Programme, UN-Water 2012; see also World Resources Institute at: http://www.wri.org/ resource/physical-and-economic-waterscarcity.

16 WWDR Managing Water under Uncertainty and Risk. 4th edition of the UN World Water Development Report (WWDR4). World Water Assessment Programme; 2012. p. 909.

17 Allan JA. Moving water to satisfy uneven global needs. Trading water as an alternative to engineering it. ICID J. 1998;47(2):1-8.

18 Chahed J, Hamdane A, Besbes M. A comprehensive water balance of Tunisia: blue water, green water and virtual water. Water Int. 2008:33;415-24.

19 Besbes M, Chahed J, Hamdane A. Sécurité Hydrique de la Tunisie, gérer l'eau en conditions de pénurie. Paris: L'Harmattan; 2014. p. 354.
20 Renault D, Wallender WW. Nutritional water productivity and diets: from crop per drop towards nutrition per drop. Agric Water Manag. 2000;45:275-96.

21 Millennium Ecosystem Assessment. Ecosystems and human well-being synthesis. Washington, DC: Island Press; 2014. ISBN 1-59726-040-1.

22 Rockström J. Magnitude of the hunger alleviation challenge: implications for consumptive use. Stockholm International Water Institute, Balancing food and environmental security. Finding opportunities for improving livelihoods. Stockholm; 2004.

23 Griffon M. Nourrir la planète. Paris, France; Odile Jacob; 2006.

24 Agrimonde. Scénarios et défis pour nourrir le monde en 2050. Coordinated by Paillard S, Treyer S, Dorin B. Versailles, France: Editions Quae; 2010.

25 FAO Food and Agricultural Organization. World food situation, cereals supply and demand brief. 2015 Mar 5. Available from: http: //www.fao.org/worldfoodsituation/csdb/en/

26 Musy A, Higy C. Hydrology, a science of nature. CRC Press; 2010. ISBN 9781578087099.

27 Gerland P, Raftery AE, Sevčíková H, Li N, Gu $\mathrm{D}$, Spoorenberg T, et al. World population stabilization unlikely this century. Science. 2014;346(6206):234-7.

28 SIWI Stockholm International Water Institute. Saving water: from field to fork. Cutting losses and wastage in the food chain. Stockholm; 2008. 